Review

\title{
Iodine Supplementation in the Newborn
}

\author{
Paolo Ghirri *, Sara Lunardi and Antonio Boldrini \\ Department of Clinical and Experimental Medicine, Neonatal Intensive Care and Neonatology Unit, \\ via Roma 55, Pisa 56126, Italy; E-Mails: saralunardi@hotmail.it (S.L.); \\ antonio.boldrini@med.unipi.it (A.B.) \\ * Author to whom correspondence should be addressed; E-Mail: pghirri@med.unipi.it; \\ Tel./Fax: +39-050-992529.
}

Received: 27 October 2013; in revised form: 29 November 2013 / Accepted: 20 December 2013 /

Published: 20 January 2014

\begin{abstract}
Iodine deficiency can be defined as the world's greatest single cause of preventable brain damage. Fetal and neonatal hypothyroidism, caused by iodine deficiency can be prevented prior to conception and then during pregnancy and lactation when an adequate iodine supplementation is ensured. Extremely low birth weight preterm babies risk having a negative iodine balance status in the first weeks of life, exacerbating the hypothyroxinaemia of the prematurity. It is important to ensure that these babies are provided with an adequate iodine intake from the first days of life. Mothers and newborns should avoid environmental iodine excess during pregnancy or lactation.
\end{abstract}

Keywords: iodine deficiency; iodine supplementation; thyroid function; newborn

\section{Introduction}

Traces of iodine are present in food and water in variable amounts, depending on a number of factors. Its concentration in sea-water as iodide is about $50 \mu \mathrm{g} / \mathrm{L}$. Iodide in seawater is oxidized and volatilizes back into the soil through rain. Nevertheless, in mountainous areas or regions where frequent flooding occur the iodine water-soil cycle is slower, and water and the soil are deprived of iodine [1]. Iodine content in food is variable as it is affected by soil, irrigation, and fertilizers. Seafood usually has a higher iodine content. Iodine has a major role within the human body: it is crucial in the production of the thyroid hormone. It is absorbed by the stomach and the duodenum and then cleared from the blood by the thyroid; before being absorbed, it is converted into iodide ion. 
When the iodine intake is sufficient, the thyroid clears up about the $10 \%$ of the overall element circulating in blood, whilst in chronic iodine deficiencies this percentage can exceed $80 \%[1,2]$. The active transport of iodine to the thyroid is mediated by the Sodium-Iodine Symporter (NIS) and regulated both by the Thyroid Stimulating Hormone and the iodine concentration in blood. Iodine is then covalently bound to tyrosine residues in thyroglobulin molecules, forming monoiodotyrosine (MIT) and diiodotyrosine (DIT). Thyroid Hormones Tri-iodo-thyronine (T3) and Thyroxine (T4) originate from the combination of MIT and DIT after having been separated from thyroglobulin. Circulating T4 (the most common thyroid hormone) originates entirely from the thyroid, while T3, the active form of thyroid hormone, originates mostly from the peripheral deiodination of T4 [3]. Cleaved by the peripheral deiodinases the iodine of the thyroid hormones re-enters circulation so that it can be reused by the thyroid. The iodine in excess is cleared from the body mainly through urine $(90 \%)$ and on small amounts excreted through feces or sweat.

Iodine deficiency can be defined as the world's greatest single cause of preventable brain damage. Currently, two billion people worldwide have insufficient iodine intake and $31.5 \%$ of children in school age have insufficient iodine intake [4]. Several European countries as well are still suffering from mild iodine deficiency [5]. This statistics are the drive behind a worldwide campaign to assure an adequate supplementation.

The main strategy to enhance iodine supplementation so far is the Universal Salt Iodization: according to WHO (World Health Organization), UNICEF (United Nations International Children's Emergency Fund) and ICCIDD (International Council for the Control of Iodine Deficiency Disorders) iodine should be added at a level of $20-40 \mathrm{mg}$ on every $\mathrm{kg}$ of salt [1]. Other strategies include bread iodization, drinking or irrigation water supplementation, or animal-fodder fortification; nevertheless salt iodization is recommended as salt is virtually consumed by everyone throughout the year and iodization technology is relatively easy. Important as it is in the synthesis of thyroid hormones, iodine plays a major role in the early growth and development of many organs, particularly the brain and the central nervous system, and in many metabolic pathways [3]. Consequently, iodine insufficiency, occurring when iodine intake falls below recommended levels and the thyroid is no longer able to produce enough thyroid hormones, can impair neurodevelopment [3]. When the maternal iodine status is insufficient the fetus suffers both from lack of the maternal T4, in a period during which the fetal hypothalamic axis is not fully functioning yet, and from impaired fetal hormones production as a consequence to the limited fruition of placental iodine. Iodine deficiency is a major threat during pregnancy and early childhood as these periods are critical in the development of the neural system of the fetus and the child.

Disorders caused by severe iodine deficiency before or during pregnancy range from decreased fertility to trophoblastic or embryonic damage, miscarriage, stillbirth or increased infant mortality, cretinism, congenital abnormalities, and psychomotor defects. Neonatal iodine deficiency causes neonatal goiter and can lead to moderate to severe hypothyroidism [3]. Two different forms of severe neonatal hypothyroidism were recognized in the original description of cretinism [1]: neurological cretinism, which consists in its most acute form of severe mental retardation, squint, deafness, and motor spasticity; and myxedematous cretinism that leads to severe growth retardation with short stature and the typical features of hypothyroidism (but less severe mental retardation) [1]. It is likely that neurological cretinism is related to maternal iodine deficiency in the early period of pregnancy 
while the myxedematous form seems to be related to a lack of iodine in the late pregnancy stages or in the first months of life [6].

Goiter, hypothyroidism, and impaired cognitive function can also occur during childhood or adolescence if iodine supplementation is not sufficient [7].

\section{Assessing Iodine Deficiency}

Urinary iodine (UI) is a sensible marker of the recent iodine intake. Iodine in excess is mostly excreted in urine. Even if the iodine urinary excretion in an individual varies on a daily basis, its concentration can be a reliable marker of the recent iodine intake when considering a statistically significant number of samples for a certain population. Iodine deficiency is considered to be a major problem when the median UI falls below $100 \mu \mathrm{g} / \mathrm{L}[1,4,8]$ (Table 1).

Table 1. Urinary iodine concentration and iodine intake $[1,4,8]$.

\begin{tabular}{cccccc}
\hline \multirow{2}{*}{$\begin{array}{c}\text { Iodine } \\
\text { Intake }\end{array}$} & \multicolumn{5}{c}{ Median Urinary iodine Concentration } \\
\cline { 2 - 6 } & $\begin{array}{c}\text { General } \\
\text { Population }\end{array}$ & $\begin{array}{c}\text { Pregnant } \\
\text { Women }\end{array}$ & $\begin{array}{c}\text { Lactating } \\
\text { Women }\end{array}$ & $\begin{array}{c}\text { Children }< \\
\text { 2 Years Old }\end{array}$ & $\begin{array}{c}\text { School-Aged } \\
\text { Children }\end{array}$ \\
\hline Insufficient & $<100 \mu \mathrm{g} / \mathrm{L}$ & $<150 \mu \mathrm{g} / \mathrm{L}$ & $<100 \mu \mathrm{g} / \mathrm{L}$ & $<100 \mu \mathrm{g} / \mathrm{L}$ & $<100 \mu \mathrm{g} / \mathrm{L}$ \\
Adequate & $100-199 \mu \mathrm{g} / \mathrm{L}$ & $150-249 \mu \mathrm{g} / \mathrm{L}$ & $\geq 100 \mu \mathrm{g} / \mathrm{L}$ & $\geq 100 \mu \mathrm{g} / \mathrm{L}$ & $100-199 \mu \mathrm{g} / \mathrm{L}$ \\
More than & $200-299 \mu \mathrm{g} / \mathrm{L}$ & $250-499 \mu \mathrm{g} / \mathrm{L}$ & - & - & $200-299 \mu \mathrm{g} / \mathrm{L}$ \\
adequate & & - & $>180 \mu \mathrm{g} / \mathrm{L}$ & $>300 \mu \mathrm{g} / \mathrm{L}$ \\
Excessive & $>300 \mu \mathrm{g} / \mathrm{L}$ & $\geq 500 \mu \mathrm{g} / \mathrm{L}$ & - & & \\
\hline
\end{tabular}

Even if UI is a reliable marker of the iodine status in a certain population, it cannot be used for individual diagnosis and treatment. It would be necessary to collect repeated urine samples from an individual over a period of time in order to correctly evaluate its iodine status [8]. It can be challenging to correctly identify the iodine status in a patient during pregnancy or lactation [9]. Iodine is concentrated in the mammary glands, hence the UI can lead to underestimate iodine intake.

Goiter rate, serum TSH, or Tg levels as well are useful assessments to determine the iodine status in a population, while the measurement of thyroid hormones remains a fairly unprecise methodology for this endeavor. The UI is a marker for recent iodine intake, whilst goiter rate marks a long-term response to iodine deficiency. The latter can be evaluated via neck inspection and palpation or through ultrasound scan and it can identify the severity of iodine deficiency in a population. We identify iodine-sufficiency when the goiter rate is below the 5\%. Goiter rates ranging from 5\% to $19.8 \%$ identify mild deficiency areas, moderately deficient areas ranges between $20 \%$ and $29.9 \%$ while severely deficient regions have goiter rates pushing above $30 \%$ [1].

TSH could be used as a sensible marker in the neonatal period (it seems to be a reliable indicator of even marginal deficiency when measured at three to four days of age) while it is a relatively insensitive indicator in older children or in adults. The World Health Organization (WHO) has suggested that, when a sensitive Assay is used on samples collected three to four days after birth, a $<3 \%$ frequency of TSH concentrations $>5 \mathrm{mIU} / \mathrm{L}$ indicates iodine sufficiency in a population [10]. Thyroid hormones usually show a variably increased TSH with lower serum T4 and normal/high levels of T3. 
$\mathrm{Tg}$ is a sensitive indicator of both low and excess iodine intake (a median $\mathrm{Tg}$ that is lower than $13 \mu \mathrm{g} / \mathrm{L}$ indicates iodine sufficiency in a population) [11]. Crucially, it is also an early marker of iodine repletion (it falls quickly after iodine supplementation has started); there is, nevertheless, a risk of underestimation when anti-Tg antibodies are present.

It is important to remember that during pregnancy a small decrease in the concentration of serum free T4, a moderate increase of thyroglobulin ( $\mathrm{Tg}$ ) levels or an increase in TSH or Tg levels in cord blood samples are not signs of iodine deficiency.

\section{Recommended Dosages of Daily Supplementation According to Age}

Several studies have tried to estimate iodine requirements. In 2001, the U.S. Institute of Medicine (IOM) published its recommendation regarding iodine intake using three different categories of dietary reference intakes. The three categories are: Estimated Average Requirements (EAR), which indicates the daily intake necessary to meet the criterion of adequacy for a certain group of people (the nutrient intake of a population is satisfactory when $97 \%-98 \%$ of individuals meet the EAR [12]), Adequate Intake (AI), which is obtained by experimental observation and used when there is not enough scientific evidence to calculate an EAR, and Recommended Daily Allowance (RDA), which is the average daily intake sufficient to provide the gender and age target requirements in nearly all individuals and is defined as the EAR plus twice the coefficient of variation in the population (or as the $140 \%$ of the EAR) [13] (see Table 2).

Table 2. Recommended iodine intakes.

\begin{tabular}{|c|c|c|c|c|c|}
\hline Source & $\begin{array}{c}\text { Women of } \\
\text { Reproductive } \\
\text { Age }(\mu \mathrm{g} / \text { day }) \\
\end{array}$ & $\begin{array}{l}\text { Pregnant } \\
\text { Women } \\
(\mu \mathrm{g} / \mathrm{day})\end{array}$ & $\begin{array}{c}\text { Lactating } \\
\text { Women } \\
(\mu \mathrm{g} / \mathrm{day})\end{array}$ & $\begin{array}{c}\text { Newborns and } \\
\text { Infants }(\mu \mathrm{g} / \text { day })\end{array}$ & $\begin{array}{c}\text { School Aged } \\
\text { Children }(\mu \mathrm{g} / \mathrm{day})\end{array}$ \\
\hline $\begin{array}{l}\text { Institute of } \\
\text { Medicine } \\
\text { (IOM), } 2001\end{array}$ & $\begin{array}{l}95^{* *} \\
150^{\circ}\end{array}$ & $\begin{array}{l}160 * * \\
220^{\circ}\end{array}$ & $\begin{array}{l}209^{* *} \\
290^{\circ}\end{array}$ & $\begin{array}{c}110 \text { (0-6 months) * } \\
130 \text { ( } 7-12 \text { months }) * \\
65(1-3 \text { years }) * * \\
90(1-3 \text { years })^{\circ}\end{array}$ & $\begin{array}{c}65 \text { ( } 4-8 \text { years) ** } \\
73 \text { ( } 9-13 \text { years }) * * \\
95(14-18 \text { years }) \text { ** } \\
90(4-8 \text { years })^{\circ} \\
120(9-13 \text { years })^{\circ} \\
150(14-18 \text { years })^{\circ}\end{array}$ \\
\hline Delange, 2004 & - & $250-300$ & $225-350$ & 90 & - \\
\hline WHO, 2007 & 150 & 250 & 250 & 90 & 120 (6-12 years) \\
\hline
\end{tabular}

In 2004, Delange [14] suggested his recommended iodine dosage after a critical review of the relevant literature. The doses he suggested were 250-300 $\mu \mathrm{g} /$ day during pregnancy, $225-350 \mu \mathrm{g} /$ day during lactation, and $90 \mu \mathrm{g} /$ day during the neonatal period.

In 2007, the World Health Organization (WHO) suggested [15], for regions where $<90 \%$ of households have access to iodized salt, a daily dose of iodine supplementation of $250 \mu \mathrm{g}$ in pregnant or lactating women, a daily dose of $150 \mu \mathrm{g}$ in women of reproductive age-15-49 years - and a daily dose of $90 \mu \mathrm{g}$ in children below two years of age. Infants' requirements have been calculated roughly on the average iodine intake of a healthy baby fed on human milk. Considering that the average iodine 
concentration in breast milk appears to be about $150-180 \mu \mathrm{g} / \mathrm{L}$ in iodine-sufficient areas, the daily iodine production by a mother during lactation has been estimated at about 75-180 $\mu \mathrm{g} / \mathrm{day}$ [1]. Children within six months of age should only receive iodine through breast milk from well-supplemented lactating mothers, or through formula milk with adequate iodine content. Children aged seven to 24 months should rather receive supplements as indicated, but only if complementary iodine-fortified food is not available. The daily intake for school-age children is $120 \mu \mathrm{g}$ [16]. The daily iodine intake, beyond which no health benefit is expected, is $500 \mu \mathrm{g}$ for pregnant or lactating women (but the safe upper limit for chronic iodine ingestion is not well defined [17]) and $180 \mu \mathrm{g}$ for children of less than two years age. Theoretically, iodine levels that are greater than those listed above could impair thyroid function. Newborns are particularly at risk as their gland is immature, and, hence, unable to reduce the iodine uptake from blood as a response to excessive exogenous iodine intake (Wolff-Chaikoff effect). This last factor explains why transient hypothyroidism or transient increased TSH in the newborn can be a consequence of maternal iodine overload (e.g., after the use of povidone iodine) especially in areas of moderate deficiency.

\section{Iodine Deficiency in the Newborn}

Studies conducted on healthy preterm and full-term newborns lead to believe that the iodine intakes required to maintain a positive balance are $15 \mu \mathrm{g} / \mathrm{kg} /$ day in full-term newborns and $30 \mu \mathrm{g} / \mathrm{kg} / \mathrm{day}$ and up to $60 \mu \mathrm{g} / \mathrm{kg} /$ day in preterm babies [14]. In fact, as far as preterm babies are concerned, iodine deficiency could exacerbate transient hypothyroxinaemia and neither parenteral nutrition nor formula milk completely fulfill the iodine requirements. Nevertheless, there is no real evidence that iodine supplementation decrease morbidity or mortality in preterm babies [18].

Many experts do not recommend routine iodine supplementation in premature babies fed on parenteral nutrition. This is because these babies already receive enough iodine by cutaneous medicaments (disinfectants) or other adventitious sources of iodine (e.g., IV infusions) [19]. The Committee on Clinical Practice Issues of the American Society of Clinical Nutrition recommended, for the preterm infant, parenteral intakes of iodine of $1 \mu \mathrm{g} / \mathrm{kg} /$ day even though this is far below their requirements [20,21].

However, in recent years many efforts have been made towards a "free from iodine excess" environment in Obstetrics and Neonatology Units and, for this reason, the "environmental" iodine should not be considered anymore as a valuable source.

A research published on the Cochrane Database in 2006 [18] on randomized or quasi-randomized controlled trials - compares a policy of supplementing enteral or parenteral feeding with iodine (more than $30 \mu \mathrm{g} / \mathrm{kg} /$ day) $v s$. placebo or no supplementation in preterm infants, concluding that there were no sufficient data to determine whether iodine supplementation could reduce mortality or morbidity in preterm babies. No clear data has shown as yet the benefits of prophylactic thyroid hormones in preterm infants, in order to reduce neonatal mortality, neonatal morbidity, or improve neurodevelopment outcomes so far [22]; a small number of infants enrolled in the tests that document this review does not allow to detect moderate, yet clinically important differences on the effects of thyroid hormone therapy in preterm infants. Preterm babies born before 30 weeks of gestation are prone to transient hypothyroxinaemia. If hypothyroxinemia appears within a crucial period for brain 
development, preterm babies require particular care in terms of iodine supplementation in order to mimic, as much as possible, intrauterine hormone environment [23,24].

The cause of hypothyroxinaemia in preterm babies is not fully clear. Iodine deficiency contributes to about $30 \%$ of cases in enterally fed preterm infants within 27 to 30 weeks of gestation, however, this contribution can be greater in younger babies who have a very low parenteral iodine supply [23].

According to literature, an enteral intake of at least 30-40 $\mu \mathrm{g}$ iodine $/ \mathrm{kg} / \mathrm{day}$ is required in order to achieve a positive iodine balance in healthy preterm infants. The ESPGHAN (European Society for Paediatric Gastroenterology, Hepatology and Nutrition) Committee on Nutrition, for example, recommends from 11 to $55 \mu \mathrm{g} / \mathrm{kg} /$ day [25]. As the iodine content of preterm formula varies from about 7 to $25 \mu \mathrm{g} / \mathrm{dL}$ (Table 3), the formula iodine content will not always meet the suggested intakes [26].

It is important to remember that iodine content in milk from mothers of preterm babies seems to be lower than that of mothers of term babies $(100-150 \mu \mathrm{g} / \mathrm{L} v s .150-180 \mu \mathrm{g} / \mathrm{L})$. Adding fortifiers to maternal milk raises iodine content to $20-25 \mu \mathrm{g} / \mathrm{dL}$. The current standard regimes of parenteral nutrition ensure an iodine intake of about $3 \mu \mathrm{g} / \mathrm{kg} / \mathrm{day}$ (at $150 \mathrm{~mL} / \mathrm{kg} / \mathrm{day}$ ), thus, most infants suffer a negative iodine balance in the first weeks of life.

Table 3. Some of commonly used Preterm Infant Formulas: iodine content.

\begin{tabular}{cc}
\hline Milk & Iodine $(\boldsymbol{\mu g} / \mathbf{1 0 0} \mathbf{~ m L})$ \\
\hline Plasmon 0 & 25 \\
Pre Aptamil & 25 \\
\hline Aptamil PDF & 20 \\
Mellin 0 Post & 20 \\
Pre Nidina & 17.3 \\
\hline Humana 0B & 15 \\
Miltina 0 & 15 \\
\hline Pre Humana & 12 \\
Formulat 0 & 7.4 \\
\hline
\end{tabular}

\section{Conclusions}

Iodine deficiency can be defined as the world's greatest single cause of preventable brain damage. Important in the synthesis of thyroid hormones, iodine plays a major role in the early growth and development of many organs, particularly the brain and the central nervous system, and in many metabolic pathways. Consequently iodine insufficiency occurring during pregnancy and early infancy, if the maternal/fetal or neonatal thyroid is no longer able to produce enough thyroid hormones, can impair neuro-cognitive development.

Urinary iodine (UI) is a sensible marker of recent iodine intake but it is not reliable for individual diagnosis and treatment as it would be necessary to collect repeated urine samples from an individual over a period of time in order to evaluate its iodine status. Goiter rate, serum TSH, or Tg levels as well are used to assess the iodine status in a population, while thyroid hormones measurement remains a fairly unprecise methodology for the detection of iodine deficiency.

Further research will be useful for better defining methods of assessment of iodine intake and iodine status [27]. Prevention of fetal and neonatal hypothyroidism, caused by iodine deficiency, starts 
prior to conception and then continues during pregnancy and lactation ensuring an adequate iodine supplementation. Studies on healthy preterm and full-term newborns lead to believe that the iodine intake required to maintain a positive balance are $15 \mu \mathrm{g} / \mathrm{kg} /$ day in full-term newborns and $30 \mu \mathrm{g} / \mathrm{kg} / \mathrm{day}$, and up to $60 \mu \mathrm{g} / \mathrm{kg} / \mathrm{day}$, in preterm babies. In the term newborn, an adequate iodine intake is granted from the first days of age if he or she is formula fed or breastfed by an adequately supplemented mother. Extremely low birth-weight preterm babies (newborns with a birth weight below $1000 \mathrm{~g}$ ) are at risk of having a negative iodine balance status in the first weeks of life, exacerbating the hypothyroxinaemia of prematurity. It is important that an adequate iodine intake is provided for these babies from the first days of life, nevertheless, neither parenteral nutrition or formula milk completely fulfill iodine requirements. On the other hand, iodine antiseptics should be avoided during pregnancy or lactation and in the newborn: a "free from iodine excess" environment in Obstetrics and Neonatology Units should be assured as far as possible.

More studies are required in order to clearly demonstrate the real benefits deriving from supplementation of preterm formulas [18,28], as well as further large prospective studies are urgently required to exactly define, not only the short term advantages, but also the long term positive effects (for example, on mental development) [29,30] so that a universally accepted iodine supplementation plan in preterm babies can be put in place.

\section{Acknowledgments}

We thank Andrea Tocchini for assisting in preparing the English form of the manuscript.

\section{Conflicts of Interest}

The authors declare no conflict of interest.

\section{References}

1. Zimmermann, M.B. Iodine deficiency. Endocr. Rev. 2009, 30, 376-408.

2. Yarrington, C.; Pearce, E.N. Iodine and pregnancy. J. Thyroid Res. 2011, 2011, 934104, doi:10.4061/2011/934104.

3. Spada, A.; Fugazzola, L.; Faglia, G. Malattie Della Tiroide. In Malattie del Sistema Endocrino e del Metabolismo (in Italian), 3rd ed.; Faglia, G., Ed.; McGraww-Hill: Milano, Italy, 2003; pp. 89-136.

4. De Benoist, B.; McLean, E.; Andersson, M.; Rogers, L. Iodine deficiency in 2007: Global progress since 2003. Food Nutr. Bull. 2008, 29, 195-202.

5. Trumpff, C.; de Schepper, J.; Tafforeau, J.; van Oyen, H.; Venderfaeillie, J.; Vandevijvere, S. Mild iodine deficiency in pregnancy in Europe and its consequences for cognitive and psychomotor development of children: A review. J. Trace Elem. Med. Biol. 2013, 27, 174-183.

6. Aghini Lombardi, F.; Fenzi, G. Ipotiroidismo da Carenza Iodica e Cretinismo Endemico. In Ipotiroidismo; Mediserve: Naples, Italy, 2009; pp. 41-55.

7. Food and Agriculture Organization of the United Nations. Human Vitamin and Mineral Requirements; Report of a Joint FAO/WHO Expert Consultation: Bangkok, Thailand, 2001; pp. 181-194. 
8. Andersson, M.; de Benoist, B.; Delange, F.; Zupan, J. Prevention and control of iodine deficiency in pregnant and lactating women and in children less than 2 years old: Conclusions and recommendations of the Technical Consultation. Public Health Nutr. 2007, 10, 1606-1611.

9. Laurberga, P.; Andersena, S.; Bjarnadóttira, R.I.; Carléa, A.; Hreidarssona, A.B.; Knudsena, N.; Ovesena, L.; Pedersen, I.B.; Rasmussena, L.B. Evaluating iodine deficiency in pregnant women and young infants - Complex physiology with a risk of misinterpretation. Public Health Nutr. 2007, 10, 1547-1552.

10. Li, M.; Eastman, C.J. Neonatal TSH screening: Is it a sensitive and reliable tool for monitoring iodine status in populations? Best Pract. Res. Clin. Endocrinol. Metab. 2010, 24, 63-75.

11. Zimmermann, M.B.; Aeberli, I.; Andersson, M.; Assey, V.; Yorg, J.A.; Jooste, P.; Jukić, T.; Kartono, D.; Kusić, Z.; Pretell, E.; et al. Thyroglobulin is a sensitive measure of both deficient and excess iodine intakes in children and indicates no adverse effects on thyroid function in the UIC range of 100-299 $\mu \mathrm{g} / \mathrm{L}$ : A UNICEF/ICCIDD study group report. J. Clin. Endocrinol. Metab. 2013, 98, 1271-1280.

12. Zimmermann, M.B.; Andersson, M. Assessment of iodine nutrition in populations: Past, present, and future. Nutr. Rev. 2012, 70, 553-570.

13. Institute of Medicine, Academy of Sciences 2001. Dietary Reference Intakes for Vitamin A, Vitamin K, Arsenic, Boron, Chromium, Copper, Iodine, Iron, Manganese, Molybdenum, Nickel, Silicon, Vanadium, and Zinc; National Academy Press: Washington, DC, USA, 2001.

14. Delange, F. Optimal iodine nutrition during pregnancy, lactation and the neonatal period. Int. J. Endocrinol. Metab. 2004, 2, 1-12.

15. World Health Organization. Reaching Optimal Iodine Nutrition in Pregnant and Lactating Women and Young Children World. Available online: http://www.who.int/nutrition/publications/ WHOStatement_IDD_pregnancy.pdf (accessed on 7 January 2014).

16. UNICEF. The State of the World's Children 2008: Child Survival; UNICEF: New York, NY, USA, 2007.

17. Pearce, E.N. Effects of iodine deficiency in pregnancy. J. Trace Elem. Med. Biol. 2012, 26, 131-133.

18. Ibrahim, M.; Sinn, J.; McGuire, W. Iodine supplementation for the prevention of mortality and adverse neurodevelopmental outcomes in preterm infants. Cochrane Database Syst. Rev. 2006, 2, CD005253.

19. Harry, L.; Greene, K.; Hambidge, M.; Schanler, R.; Tsang, M.R.C. Guidelines for the use of vitamins, trace elements, calcium, magnesium, and phosphorus in infants and children receiving total parenteral nutrition: Report of the subcommittee on pediatric parenteral nutrient requirements from the committee on clinical practice issues of the American society for clinical nutrition. Am. J. Clin. Nutr. 1988, 48, 1324-1342.

20. Reifen, R.M. Microminerals. In Nutritional Needs of the Preterm Infant: Scientific Basis and Practical Guidelines; Tsang, R., Luca, A., Uauy, R., Zlotkin, S., Eds.; Williams \& Wilkins: Philadelphia, PA, USA, 1993; pp. 195-242.

21. Zimmermann, M.B.; Crill, C.M. Iodine in enteral and parenteral nutrition. Best Pract. Res. Clin. Endocrinol. Metab. 2010, 24, 143-158.

22. Osborn, D.A.; Hunt, R.W. Prophylactic postnatal thyroid hormones for prevention of morbidity and mortality in preterm infants. Cochrane Database Syst. Rev. 2007, 24, CD005948. 
23. Ibrahim, M.; Morreale de Escobar, G.; Visser, T.J.; Durán, S.; van Toor, H.; Strachan, J.; Williams, F.L.R.; Hume, R. Iodine deficiency associated with parenteral nutrition in extreme preterm infants. Arch. Dis. Child. Fetal Neonatal Ed. 2003, 88, F56-F57.

24. Ares, S.; Escobar-Morreale, H.F.; Quero, J.; Durán, S.; Presas, M.J.; Herruzo, R.; Morreale de Escobar, G. Neonatal hypothyroxinemia: Effects of iodine intake and premature birth. J. Clin. Endocrinol. Metab. 1997, 82, 1704-1712.

25. ESPGHAN Committee on Nutrition. Enteral nutrient supply for preterm infants: Commentary from the european society for paediatric gastroenterology, hepatology, and nutrition committee on nutrition. JPGN 2010, 50, 85-91.

26. Belfort, M.B.; Pearce, E.N.; Braverman, L.E.; He, X.; Brown, R.S. Low iodine content in the diets of hospitalized preterm infants. J. Clin. Endocrinol. Metab. 2012, 97, E632-E636.

27. Swanson, C.A.; Zimmermann, M.B.; Skeaff, S.; Pearce, E.N.; Dwyer, J.T.; Trumbo, P.R.; Zehaluk, C.; Andrews, K.W.; Carriquiry, A.; Caldwell, K.L.; et al. Summary of an NIH workshop to identify research needs to improve the monitoring of iodine status in the United States and to inform the DRI. J. Nutr. 2012, 142, 1175S-1185S.

28. Rogahn, J.; Ryan, S.; Wells, J.; Fraser, B.; Squire, C.; Wild, N.; Hughes, A.; Amegavie, L. Randomised trial of iodine intake and thyroid status in preterm infants. Arch. Dis. Child. Fetal Neonatal Ed. 2000, 83, F86-F90.

29. Taylor, P.N.; Okosieme, O.E.; Dayan, C.M.; Lazarus, J.H. Impact of iodine supplementation in mild-to-moderate iodine deficiency: Systematic review and meta-analysis. Eur. J. Endocrinol. 2013, 170, R1-R15.

30. Bougma, K.; Aboud, F.E.; Harding, K.B.; Marquis, G.S. Iodine and mental development of children 5 years old and under: A systematic review and meta-analysis. Nutrients 2013, 5, 1384-1416.

(C) 2014 by the authors; licensee MDPI, Basel, Switzerland. This article is an open access article distributed under the terms and conditions of the Creative Commons Attribution license (http://creativecommons.org/licenses/by/3.0/). 